\title{
Democracy in Nigeria: Real or Myhtic
}

\author{
Peter Bisong Bisong Samuel Aloysius Ekanem \\ Department of Philosophy, University of Calabar
}

\begin{abstract}
This paper attempts to answer one of the most debated questions in Nigeria: is Nigeria's democracy a reality or an illusion? Our answer to the question is that, though no government can claim to possess all the elements of democracy, but a government must possess some elements of democracy to a high degree before it could be termed democratic. By our assessment, the Nigerian government does not possess enough of this and thus cannot justifiably claim to be democratic. It possesses more of the element of authoritarianism than that of democracy and thus could be properly called authoritarian democracy. Democracy in Nigeria is therefore a myth and not a reality. The choice and assessment of Nigeria's government as authoritarian democracy is premised on the fact that at least, elections or selection of candidates have been taking place for about 16 (sixteen) years now.
\end{abstract}

DOI: $10.7176 / \mathrm{JPCR} / 50-01$

Publication date:August $31^{\text {st }} 2020$

\section{INTRODUCTION}

Democracy has become a daunting challenge in Nigeria. Over the years, the Nigerian democratic government has failed to harness the vast human and material resources to break free from the cycle of poverty and illiteracy that has characterized it since independence. The Nigerian state has therefore been constantly struggling between the forces of democracy and authoritarianism.

And, to the opinion of this paper, it has deviated from the known curve of democracy to authoritarianism; for rather than being at the service of the people, it is in the service of the ruling oligarchy - enriching them beyond measures.

The standard of living has worsened under the democratic dispensation. The poverty level has increased. Life expectancy has reduced drastically. The educational standard is nose-diving. Life and properties have become more insecure. The level of corruption has increased (Bisong \& Ekanem, 2014, 13-14). These all point to a government that is far from democratic; for democracy will always carry with it, its dividends.

In essence, a democratic system is judged according to the degree of its commitment to the principles of democracy - those countries with high degree of commitment like America could be called democratic but countries like Nigeria with a low level of commitment can at best be called tyrannical or authoritarian and not democratic. Democracy thrives where people freely stand for election and vote during election; where freedom of speech, publication and association are allowed; where the government and its functionaries stick to the rule of law; where power is vested on the people; where there is political tolerance; where elections conducted are free, fair and credible; where defeated leaders accept defeat freely in an election; where succession process is smooth and not problematic; where the individual is allowed to freely make his/her choice; where the rulers are transparent and accountable; where the judiciary is independent; where there is equality before the law; and where the process of election is competitive among the political parties. If all these tenets, principles, and parameters are adhered to, a government can be regarded as being democratic. These are not adhered to in Nigeria, thus Nigeria could be said not to be democratic but best described in the opinion of this paper as authoritarian democracy.

This paper argues that Nigeria's claim of being democratic is only a myth and not real. This is because, Nigerian government has failed to reflect the basic principles of a democratic regime. We are in an era where all forms of government claim to be democratic so as to attract legitimacy (Bisong 2018, 36). We think Nigeria is one of such government that is merely democratic by name to gain credibility in the eyes of the world. This is not to say that Nigerian government has no element of democracy, but the degree of this made it to fall properly under authoritarian rule than democracy - the elements of democracy it possess are not enough to put it in the cadre of democratic countries.

\section{THE MEANING OF DEMOCRACY}

The term democracy originates from the Greek word demokratia which is a coinage from two words: demos meaning "people" and krátos meaning "power" or "rule". Etymologically therefore, democracy means rule of the people. Its origin is traceable to the 5th century BC where it was used in Greek city-states, notably Athens (Wilson 511).

Democracy is a form of government where the law reflects the will of majority of the people of a state as determined by direct vote or elected representatives (Marlinspike \&Hart http//theanarchistlibrary.org). It is a government where the citizens choose and replace the government through elections. The legitimacy of a democratic government typically begins with the adoption of a constitution, which puts forth the basic rules, principles, powers and duties of the government and the rights of the people against the government. Democratic 
governments allow active participation of the citizens in politics and civic life, protect the human rights of all and apply laws and procedures equally to all citizens (Diamond \& Plartner 1). Karl Popper as noted by Jarvie defined democracy in contrast to dictatorship or tyranny, as a government that afford the people the opportunities to control their leaders and to oust them without the need for a revolution (219). According to Elijah John, democracy is a "method of government through which leaders are held accountable for their actions and inactions in the public realm, and by which citizens are actively involved in the completion and cooperation of their elected representatives" (Man and the State 68). Within the logical ambit of this paper, the term democracy nonetheless implies and not limited to the freedom of a people to actively participate without any iota of clog, in the process of transparently electing their representatives. It is the exercise of liberty to reject a candidate who in the wisdom of the people not credible to lead the people.

Democracy contrasts with forms of government where the state is controlled by a single individual, like in absolute monarchy, or where the state is controlled by a small number of individuals, as in an oligarchy. Nevertheless, these oppositions, which came from ancient Greek Philosophy, are now ambiguous because there is hardly any government in the world today that is purely democratic, monarchic or oligarchic - there all have mixed elements of democracy, oligarchy, and monarchy. The marks of democracy according to Elijah include:

1. An atmosphere of political, legal, economic and social equality, freedom and justice

2. The opportunity for political participation either directly or through representatives, periodically elected; and

3. The possibility of an alternative government (Man and Knowledge, 215).

Democracy has many forms which are classified under two broad groups: direct and representative democracy. Direct democracy is a form of democracy where the citizens participate in the decision-making of the state personally. A direct democracy gives the entire voting population the power to:

1. Change constitutional laws when necessary,

2. Formulate initiatives, referendums and suggestions for laws,

3. Give binding orders to elective officials, such as revoking them before the end of their elected term, or initiating a lawsuit for breaking a campaign promise.

\section{THE BASIC PRINCIPLES OF DEMOCRACY}

Though there are many variants of democracy as we have alluded to already but they all share these basic features 1. Existence of a constitution: In a democracy law-making must take place within certain parameters; there must be approved methods for laws to be enacted and changed, and the rights of the individuals must be properly set. All these are contained in a constitution..

2. Regular, free and fair elections: No government no matter how well structured can be called democratic if the officials who head the government are not freely elected by the citizens in a way that is perceived to be open and fair (Urofsky http://www.ait.org.tw). Though the mechanism of the election may be different, in different democracies, but the essentials are the same for all - there must be access of all qualified citizens to the ballot, protection of the individual against duress or undue influence during the casting of the ballot, an open and honest counting of the ballots.

3. Existence of Federalism: in all democracies power and authority is shared into three federal, state and local governments. This is aimed at ensuring that government is nearer to the people, and also gives the people the opportunity to understands and x-ray the dyanmics of government policies..

4. An independent judiciary: the judiciary in a democracy is independent and powerful. The courts may declare acts of state and federal legislatures invalid because they conflict with the Constitution, and may also enjoin presidential actions on similar charge.

5. Powers of the presidency: The powers of the president in a democracy are constrained by principles as 'separation of powers'. Thus, while the president has the powers to carry out the responsibilities of government; he is prevented by the constraints imposed on him to become a tyrant. The powers of the presidency are therefore derived from the people.

6. A free media: since the powers of the democratic government are derived from the people, they have the right to know which is closely related to a free media. Thus in a democracy the newspapers, television, radios networks are free to investigate the activities of government and report on them without fear of prosecution.

7. Transparency: the democratic government is expected to be transparent respecting the people's right to know. This means its deliberations and decisions should be open to public scrutiny.

8. Civilian control of the military: In a democracy the military is under the control of civilian authorities. The military role is to protect democracy and not to rule.

9. Multi-party system: This is a great feature of democracy. The reasons for having multiple parties in a democracy include: to widen the chances for the choice of the best candidate for political office; to offer alternative views to the existing government and to enable the opposition to act as a check on those in political office. Oneparty system lead to a lack of alternatives for the citizens and concentrate powers on the existing government 
which often lead to dictatorship.

10. Equality before the law: in democratic government all citizens are seen as equal before the law. This means there is equality of opportunity in the realisation of individual potentials not minding the race, gender, ethnic background, religion deformity etc for all.

11. Political tolerance: in a democracy the ruling masses are mindful and respectful of the interests of the minority. While there may be differences between the people by way of race, religion, descent and culture they rise above such differences and give room for discussion, debate and accommodation of different viewpoints.

12. Accountability: This is a principle that requires all elected public officials to answer to the citizens as regards their actions and decisions during the time they are or were occupants of the public offices.

13. Human rights: All democracies strive to protect the rights and freedoms of their citizens from violations and abuse.

14. Neutrality of state institutions: In a democracy all state institutions such as the police, civil defence, road safety, the army etc are neutral and do not take sides; they are politically nonpartisan. Their functions are to protect and preserve the sanctity of the state from internal and external strife.

15. Rule of law: Democratic government operate based on the principle of the rule of law. The principle implies that no one is above the law and demands that all citizens should observe the law and be held accountable if they break it.

\section{The State of Nigeria's Democracy}

When these principles are analysed side by side with the Nigerian government, it will be difficult to argue that Nigeria is practicing democracy. Before we analyse, we will first scan the Nigerian political scene to discover how democracy is faring in the country.

The first major problem that could be discerned in the political environment of Nigeria is that the political elites do not believe in elections. They seek and desire power but do not believe in competition or competitive politics. The political parties in the country instead of strategizing on how to best present their manifestoes to convince the electorate to cast their votes for them, rather strategize on how to rig. The party that wins the election is always the one whose rigging strategy worked best. The rest of the parties take to the courts not because they were clean themselves but because they were outsmarted. In order to ensure victory at the polls, politicians and political parties in Nigeria use all forms of negative methods ranging from, assassination, kidnapping, ritual killings, intimidation, threats, bribing etc to succeed. In Nigeria therefore as captured by Anya

There is an absence of an open, established, competitive and merit-based process for recruitment into leadership position and offices in the polity, hence self promotion has hastily become the prime avenue for access to political office ... a situation that attracts all manner of men - the good, the bad and the ugly but mostly, the bad and the ugly for the good are busy looking for the non-existent rules of the game (and for fear of being mauled by blood thirst and avaricious demagogues (15).

The politicians take advantage of the poverty and ignorance of the populace to buy their votes with pittances. Obasanjo and Mabogunje lamented thus:

Because of the past experiences of failed promises and seeming betrayals - by politicians, a perceptible degree has come to permeate the general thinking of most Nigerians and has encouraged the belief that the ultimate goal of political office seekers is to amass wealth. The masses who cast their votes have thus become content to accept the highest bid as the pay off for their votes (12).

Since 1998 as expressed by Momoh, only few political office holders got to power through competitive elections (Democracy and Elections 6). This means the elections in Nigeria are not free and fair which is number one bridge of the tenets of democracy. Elections in Nigeria are flawed which according to Momoh "lead to malgovernance, democratic regression, dedemocratisation or what I called authoritarian democracy" (Democracy, De - democratisation and Development in Nigeria 45).

Institutions in the country like the police, the army, civil defence and even INEC collude to manipulate the electoral process to favour some candidates. There are cases in Nigeria where some individuals have won elections while in prison like in the case of Senator Omisore of Ogun State and Governor Arhemefuna Orji of Abia state. This reflects the poor electoral process of the country. In almost all elections, the local and international observers have expressed their dissatisfaction over the conduct of elections. The Transition Monitoring Group for instance described the 2003 election in the following words:

While the voters waited and persevered at the polling station to cast their votes, the political class and the political parties had different ideas. The voters wanted their votes to determine the winner of the election, while the political parties wanted to corrupt the process and rig their way into elective office ... on the whole the result can be said to marginally reflect the choice and will of the Nigerian people (TMG 2003, cited in Adejumobi and Agbaje, 39). 
In the same light the Human Right Watch report of 2007 elections declared as follows:

The polls marked a dramatic step backwards, even when measured against the dismal standard set by the 2003 elections. Electoral officers along with the very government agencies with ensuring the credibility of the polls were accused of reducing the election to a violent and fraud ridden farce (Human Right Watch 23).

Most theorists have also expressed their disappointments with the Nigerian electoral process. Omodia writes; In Nigeria, just like most other African countries, its freeness and fairness constitute the central factor in ensuring democratic survival. This is because the lack of free and fair elections often tends to threaten the democratic process as a result of legitimacy question. The factor no doubt has characterised the democratic experiment of Nigerian Fourth Republic in that there have been persistent crises of legitimacy of governance arising from poor electoral process (38).

Aside from being the cardinal tenets of democratic process, free, fair and credible elections are also necessary for the consolidation of democracy. Unfortunately, Nigeria lacks these special democratic creed.

Apart from the problem of election, widespread poverty also shows the failure of democracy in Nigeria. Democracy is acclaimed the best form of government because it is believed to be capable of providing a better life for the citizens. This is not the case in Nigeria. According to UNDP, most homes in Nigeria suffer from abject poverty, making the common man to be "alienated from himself as he lacks the wherewithal to afford the basic necessities of life such as education, medical facilities and so forth" (27). Life expectancy is also low in Nigeria compared to the developed countries of the world (Olu-Olu 1). Comparing Nigeria and India, Nda-Isiah writes

Between then and now (1962-2012), India has been able to lift up 400 million people out of poverty, just as democracy as also flourished in the population of 167 million have slipped into poverty. Statistically about 10 million Nigerians are in absolute poverty, which literally means they cannot afford the basic needs of life (56).

The above shows that poverty is increasing in Nigeria, meaning that the dividends of democracy are not yet received by Nigerians. The estimate of the Humanized Nigerian Living Standard Survey of the trend of poverty in Nigeria is shown in the table below

\begin{tabular}{|l|l|l|l|}
\hline Year & Poverty incidence (\%) & Estimated population (million) & Population in poverty (million) \\
\hline 1980 & 27.2 & 65 & 17.1 \\
\hline 1985 & 47.3 & 75 & 34.9 \\
\hline 1992 & 42.7 & 91.5 & 39.2 \\
\hline 1996 & 65.6 & 102.3 & 67.1 \\
\hline 2004 & 54.4 & 126.3 & 68.7 \\
\hline 2010 & 69.0 & 163 & 112.5 \\
\hline
\end{tabular}

National Bureau of Statistics (NBS) Harmonized Nigerian Living Standard Survey (2010)

These figures undoubtedly challenged the efficacy of the Nigerian democratic governance.

The high level of corruption is another question mark on the credibility of the Nigerian democratic governance. Nigerians "are very religious people. But religion seems to have no impact in their lives; because almost on a daily basis one hears of cases of people being swindled of their monies, or of people corruptly enriching themselves" (Ushie, Bisong \& Odok 3). Nigerians generally "ascribe to the philosophy of money acquisition, even if it means killing others" (838). Wealth in Nigeria, has been raised to the seat of supreme good (summum bonum) and thus any means used to attain it does not matter much (Bisong \& Ekanem, 58-59).

Transparency International which is the world most credible measure of the world domestic and public sector corruption, reports that every single institution in the country is corrupt. In 2008 Nigeria sank lower in the rating, a position it has retained till date. It was given

a score of 2.7 to 2.5 in 2009, and 2.4 in 2010 which it maintained in 2011, Nigeria has been ranked as the $3^{\text {rd }}$ most corrupt country in Sub-Sahara Africa and $143^{\text {rd }}$ out of 183 countries surveyed around the world in $2011 \ldots$ it is reported by Transparency International that the level of corruption and other related crimes attract between 4 million dollars and 8 million dollars loss on a daily basis and a loss of about 70.58 million dollar to the national economy annually, and that the country has lost more than 380 million dollars to graft since independence in 1960 (Ogbonnaya 291).

Corruption has remained an irredeemable part of Nigeria and according to Oko, nothing enfeebles democracy more than corruption, it distorts governance and provides perverse opportunities for negative practices (60).

\section{DEMOCRACY IN NIGERIA: MYTH OR REALITY}

It is clear from the happenings in the country that Nigeria is still far away from democracy. Almost all cherished principles of democracy are near absent in Nigeria. The rule of law is only in theory and never in practice. It is an open secret in Nigeria that justice only goes to the highest bidder - it is for sale. Equality before the law is a mirage - "there are some who are more equal." Most Nigerians are above the law - they are the 'untouchable'. The law 
catches only the less privileged.

Democracy is said to be the government where power rest on the people. In Nigeria, it is not so. The voices of the people are not heard and even their votes do not count. In Nigeria power is not in the hands of the people but rather in the hands of a few political elites, who determine whether the people live or die. The government in Nigeria could arguably be said to be closer to authoritarianism than democracy.

Democracy carries accountability and transparency as its principles, which do not exist in the Nigerian government given the way governments at various levels feel obliged to think for the citizens and consider criticisms of their policies as anathema. It is very difficult to get details of state and federal budgets in Nigeria. After the presentation of omnibus budget by the governor or president before the State or National Assembly, the commissioner or minister for finance presents the breakdown for the legislative exercises. That ends the public view of the draft budget except for the aspects that are reported in the media. Afterward an ordinary citizen cannot have access to it like through the internet or whatever means to study it and give feedback. The ordinary citizen does not have enough information as to the activities of the government functionaries which is against the twin tenets of accountability and transparency in democracy.

Human rights preservation that democracy sees as its goal is not upheld in Nigeria. Human rights of the citizens in Nigeria are everyday being violated without much being done to halt it. Almost every day we hear of killings, kidnapping, imprisonment without trial, arbitrary arrest, judicial murder, religious violence and other human right violations. This means that democracy is not performing its function of protecting human rights of citizens.

All these show that democracy is not yet a reality in Nigeria. It could at best be described as mythic. It only exists in name and not in reality. The fact that a gorilla have some features of a man, does not make it a man. The fact that Nigeria government has some features of democracy, does not make it democratic. It is more in tune with authoritarianism than democracy.

\section{Conclusion}

The definition of democracy as "Government of the people, by the people and for the people" makes the claim of Nigeria to be practicing democracy to be in question. Nigeria is far away from democracy because most of its basic principles are not found in it. We understand that no democracy in the world is perfect, but at least in most countries democracy is near the ideal. But Nigeria's democracy is so far away from the ideal that it appears to this paper that it has lost its 'democraciness'.

Democracy and authoritarian government are at opposite poles. On this pole Nigeria is closer to authoritarian government than it is to democracy and should be properly called by its name.

This is not to say that Nigeria cannot become democratic. This paper is optimistic that in future, Nigeria will wade off the tide and move away from authoritarianism to its opposite (democracy). But at present it will be mere fairy tale to classify Nigeria's civilian rulership to fall within the ambit of democracy - its democracy is more a myth than reality. If the exact components of democracy is for a civilian to mount the podium of leadership through the process of selection or choosing people by a community of persons with identical ideological trappings then, Nigeria could very well be so called. On the other string of it, if democracy involves observances of known democratic ideals such as rule of law, provision of free expression, the freedom to actively participate in political processes with the choice of determining who lead the people and to lead the people, then this paper could very well conclude that Nigeria's democracy does not fall short of authoritarianism warped to the ideals of what Ikegbu calls "the philosophy of its is my turn syndrome".(366).

\section{WORKS CITED}

Anya, C. Democracy and Development in Africa. Ibadan: Spectrum Books, 1996.

Bisong, Peter \& Mary Egbai. "The Dilemma of an Average Nigerian in Nigeria". International Journal of Development Research. 4.4 (2014): 837-839.

Bisong, Peter \& Samuel A. Ekanem. "Aristotle's concept of Happiness in the Context of Contemporary Nigeria". Flash: Journal of Philosophy and Religion. 8.1 (2014): 10-16.

Bisong, Peter \& Samuel Ekanem. "The contemporary Nigerian Summon Bonum and its effect on the Economy”. Sophia: An African Journal of Philosophy and Public Affairs. 15. 1, (2014): 57-61

Bisong, Peter. "Which way Africa: Multiparty or One Party System of Government? A move to fashion a Democracy that is truly African”. Bulletin Social-Economic and Humanitarian Research», № 2,( 2018): $36-42$

Diamond, Larry \& Marc Plattner. The Global Resurgence of Democracy. Baltimore: Johns Hopkins University Press, 1996.

Elijah, John. Man and Knowledge: Issues in Contemporary Philosophy. Uyo: Scholars Press, 1996.

Elijah, John. Man and the State: Issues in Socio-Political Philosophy. Uyo: Afahaide \& Brothers Publishing Co, 2009. 
Human Right Watch. Criminal Politics: Godfathers and Corruption in Nigeria. http://www.hrg.org. retrieved February 12, 2015.

Ikegbu, Ephraim. "Dealing with Self Centredness in National Assembly Business". Nigeria: Citizenship Education. Eds. G. O.Ozumba, F. O. Eteng \& M. Okom. Aba: A.A.U Vitalis Book, 2012.

Jarvie, I. C.; Milford, K. Karl Popper: Life and time, and values in a world of facts Volume 1 of Karl Popper: A Centenary Assessment, Karl Milford. Ashgate Publishing, Ltd, 2006.

Marlinspike, Moxie \& Windy Hart. An Anarchist Critique of Democracy. http://theanarchistlibrary.org. Retrieved January 30, 2015.

Momoh, Abubakar. "Democracy, De - democratisation and Development in Nigeria" Nigerian Journal of International Affairs. 32.2, (2006): 13-26.

Momoh, Abubakar. Democracy and Elections: Myth, Illusions and Reality. 3rd Annual Law and Social Development Lecture. Ikeja, October 25, 2010.

Obasanjo, O. \& Mabogunje, A. Elements of Democracy: A Farm House Dialogue. Abeokuta: ALF Publishers, 1992.

Ogbonnaya, Ufiem; Oluwasola Omujo \& Ndadozie Udofona. The challenge of Democratic Governance in Nigeria's Fourth Republic. Mediterean Journal of Social Sciences. 3.11 (2012): 685-693.

Oko, O. The challenges of Democratic consolidation in Africa. Http://www.works.bepress/okechukwu-oko/2. Retrieved February 12, 2015.

Olu-Olu, L. Corruption and the problem of Development in Nigeria. The Social Sciences. 1.3(2006): 183-187.

Omodia, S. Elections and Democratic survival in the Nigerian Fourth Republic”. Journal of Social Science. 24.2 (2010): 129-133.

Transition Monitoring Group (TMG), do the Votes Count. Final Report of the 2003 general Elections in Nigeria, 2003.

UNDP. Human Development Report, 2011.

Ushie, Abel; Peter Bisong \& Joseph Odok. "Aristotle's Concept of Virtue in the Context of Contemporary Nigeria Aristotle's Concept of Virtue in the Context of Contemporary Nigeria." Journal of Philosophy, Culture and Religion. Vol 7, 2015: 1-6

Wilson, N. G. Encyclopedia of Ancient Greece. New York: Routledge, 2006. 